ORNLTM-13383

OAK RIDGE

NATIONAL

LABORATORY

\title{
Source Term Evaluation for UF Release Event in Feed Facility at Gaseous Diffusion Plants
}

S. H. Kim

R. P. Taleyarkhan

RECEIVEU

AUG 061997

OSTI

MANAGED AND OPERATED BY

LOCKHEED MAATIN ENERGY RESEARCH CORPORATION FOR THE UNTED STATES

DEPARTMENT OF ENERGY 
This report has been reproduced directly from the best available copy.

Available to DOE and DOE contractors from the Office of Scientific and Technical Information, P. O. Box 62, Oak Ridge, TN 37831; prices available from (423) 576-8401, FTS 626-8401.

Available to the public from the National Technical Information Service, U.S. Department of Commerce, 5285 Port Royal Road, Springfield. VA 22161.

This report was prepared as an account of work sponsored by an agency of the United States Government. Neither the United States Government nor any agency thereof, nor any of their employees, makes any warranty, express or implied, or assumes any legal liability or responsibility for the accuracy, completeness, or usefulness of any information, apparatus, product, or process disclosed, or represents that its use would not infringe privately owned rights. Reference hercin to any specific commercial product, process, or service by trade name, trademark, manufacturer, or otherwise, does not necessarily constitute or imply its endorsement, recommendation, or favoring by the United States Govemment or any agency thereof. The views and opinions of authors expressed herein do not necessarily state or reflect those of the United States Government of any agency thereof. 


\section{DISCLAIMER}

Portions of this document may be illegible electronic image products. Images are produced from the best available original document. 


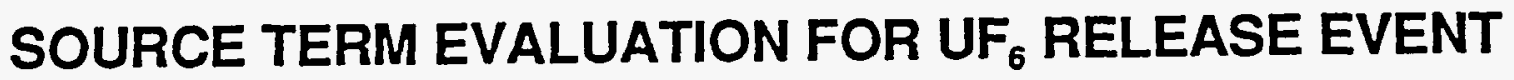 IN FEED FACILITY AT GASEOUS DIFFUSION PLANTS
}

\author{
prepared by \\ S.H. Kim \\ R.P. Taleyarkhan \\ Engineering Technology Division \\ Oak Ridge National Laboratory \\ Prepared by the \\ Oak Ridge National Laboratory \\ Oak Ridge, Tennessee 37831-8045 \\ managed by \\ LOCKHEED MARTIN ENERGY SYSTEMS, INC. \\ for the \\ U.S. DEPARTMENT OF ENERGY \\ under contract DOE-840R21400
}

January 30,1997 
TABLE OF CONTENTS

\section{Page}

Table of Contents............................................................. ii

List of Figures.................................................................... ii

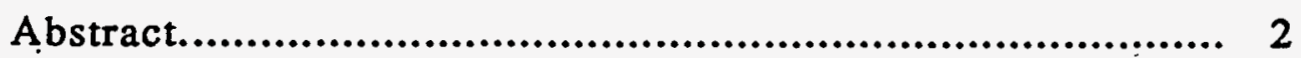

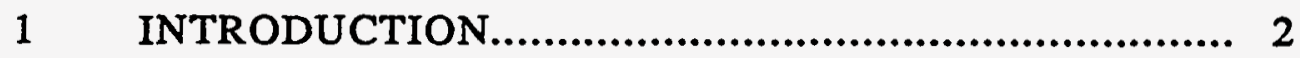

2 MODELING DESCRIPTION...................................... 3

3 RESULTS AND ANALYSIS........................................ 5

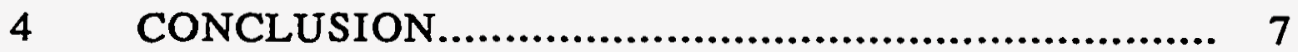




\section{LIST OF FIGURES}

PAGE

Figure 1. A Schematics of Feed Facility Building, X-343, of the Portsmouth GDP

Figure 2 Simplified Plan View Drawing of X-343 of the Portsmouth GDP .8

Figure 3 Mass Rate of $U F_{6}$ and Vapor Released into the $X-343$ Feed Facility. 9

Figure 4 MELCOR Nodalization for Source Term Evaluation from Feed Facility …................................................................................9

Figure 5 Variation of Average Temperature of Control Volumes................10

Figure 6 Mass Flow Rates Between Control Volumes....................................10

Figure 7 Mass Reaction Rate of $U F_{6}$ Vapor and Atmospheric Moisture in Various Control Volumes

Figure 8 Mass Source Term of $U O_{2} F_{2}, \mathrm{HF}$ and $U F_{6}$ Released into the Environment.

Figure $9 U F_{6}$ Vapor Mass Variation at the End of Each Time Step

Figure $10 \quad \mathrm{UO}_{2} \mathrm{~F}_{2}$ Mass Variation in Various Control Volume Atmosphere

Figure 11 Mass of $\mathrm{UO}_{2} \mathrm{~F}_{2}$ Aerosol Settled or Fall-out onto the Floor from Each Control Volume.............................................................13

Figure 12 HF Mass Variations in Control Volumes.......................................13

Figure 13 Variation of Average Temperature of Control Volumes................14

Figure 14 Mass Reaction Rate of $U F_{6}$ Vapor and Atmospheric Moisture in Various Control Volumes.............................................14

Figure 15 Mass Source Term of $U O_{2} F_{2} \mathrm{HF}$ and $U F_{6}$ Released into the Environment.......................................................................15

Figure $16 U F_{6}$ Vapor Mass Variation at the End of Each Time Step...........15 


\section{LIST OF FIGURES (CONTINUED)}

PAGE

Figure 17. $\quad \mathrm{UO}_{2} \mathrm{~F}_{2}$ Mass Variation in Various Control Volume Atmosphere.........................................................................................16

Figure 18 Mass of $\mathrm{UO}_{2} \mathrm{~F}_{2}$ Aerosol Settled or Fall-out onto the Floor from Each Control Volume......................................................16

Figure 19 HF Mass Variations in Control Volumes.....................................17 


\begin{abstract}
An assessment of $\mathrm{UF}_{6}$ release accidents was conducted for the feed facility of a gaseous diffusion plant (GDP). Release rates from pig-tail connections were estimated from CYLIND code predictions, whereas, MELCOR was utilized for simulating reactions of $\mathrm{UF}_{6}$ with moisture and consequent transport of $\mathrm{UO}_{2} \mathrm{~F}_{2}$ aerosols and $\mathrm{HF}$ vapor through the building and to the environment. Two wind speeds were utilized. At the high end (Case 1) a wind speed of $\sim 1 \mathrm{~m} / \mathrm{s}(200 \mathrm{fpm})$ was assumed to flow parallel to the building length. At the low end (Case 2) to represent stagnant conditions a corresponding wind speed of 1 $\mathrm{cm} / \mathrm{s}$ ( $2 \mathrm{fpm}$ ) was utilized. A further conservative assumption was made to specify no closure of crane and train doors at either end of the building. Relaxation of this assumption should provide for additional margins. Results indicated that, for the high ( $200 \mathrm{fpm})$ wind speed, close to $66 \%$ of the $\mathrm{UO}_{2} \mathrm{~F}_{2}$ aerosols and $100 \%$ of the HF gas get released to the environment over a 10-minute period. However, for the low ( $2 \mathrm{fpm}$ ) wind speed, negligible amount $\left(-1 \% \mathrm{UO}_{2} \mathrm{~F}_{2}\right)$ of aerosols get released even over a 2 hour period.
\end{abstract}

\title{
1. INTRODUCTION
}

All cascade feeding is performed by transferring UF $_{6}$ gas from a cylinder through a heated line into the appropriate point in the cascade that contains the same assay material as the material being fed. The feed material is received in a large cylinder which is placed in steam-heated autoclaves during feed operations. The feed facility houses multiple autoclaves and allows the train to port $\mathrm{UF}_{6}$ cylinders in and out of the building. Also the crane moves in and out of the building to transfer cylinders between the building and outdoor storage lot. To allow this train and crane access, large openings with motor-operated rolling doors are installed on both sides of the building, as seen in Fig. 1. Figure 2 illustrates a simplified plan view of X-343 at the Portsmouth Gaseous Diffusion Plant. As seen in the figure, the building is 140-foot long, 63-foot wide, and about 43.3-foot high. There are auxiliary facilities attached on the side of the building such as men's and women's locker rooms, electrical room, and air-conditioned operator room. The X-343 facility contains seven steam-heated autoclaves. All seven units are designed for feed or vapor-phase sampling operations, and are connected to the cascade feed headers. Three of the seven autoclaves have seven-foot diameters and the remaining four autoclaves have six- 
foot diameters. If a cylinder requires sampling, it is picked up with the overhead crane and placed into a feed and sampling autoclaves. The cylinder is then heated, sampled, weighed, and returned to storage with the overhead cylinder. After analysis of samples is done, cylinders are sequentially moved to one of the feed autoclaves where they are heated, the cylinder contents $\left(\mathrm{UF}_{6}\right)$ are vaporized, and transferred to the cascade through a manifold system of three feed headers, metering stations, and cascade feed piping. A flexible piping, called "pigtail", is provided between the cylinder and a manifold system of feed headers. This pigtail connection is the most vulnerable piece of equipment in the $\mathrm{UF}_{6}$

feed operations. More than one-half of all major $\mathrm{UF}_{6}$ releases have occurred at the pigtails. For the current study, therefore, $\mathrm{UF}_{6}$ is assumed to be released through broken pigtails to the atmosphere in the feed facility.

\section{MODELING DESCRIPTION}

$\mathrm{UF}_{6}$ was assumed to be released through 0.875 "-dia broken valve fitting on a pigtail from the cylinder of which internal pressure was about 88 psia and vapor temperature was $240 \mathrm{~F}$. The transient mass rate of $\mathrm{UF}_{6}$ release was calculated by $\mathrm{R}$. Schmidt using the CYLIND code for 5-min and 30-min releases. For the current study, however, only a 5-min release case has been considered. Because of the large pressure difference between internal cylinder pressure and atmospheric pressure, the code predicted $\mathrm{UF}_{6}$ vapor release as choked flow. As seen in Figure 3, $\mathrm{UF}_{6}$ was predicted to be released as vapor at about 1.7 $\sim 2 \mathrm{~kg} / \mathrm{s}(\sim 4.5 \mathrm{lb} / \mathrm{s})$ over a 5 -min period. Once the $\mathrm{UF}_{6}$ vapor is released, because of the chocked condition at the break, it will rather widely spread out, and interact with atmospheric moisture while seeking the lowest elevation to settle down because it is much denser than air ( -12 times as dense). Unreacted $\mathrm{UF}_{6}$ vapor will settle down on the floor while reaction products, $\mathrm{UO}_{2} \mathrm{~F}_{2}$ and $\mathrm{HF}$, will become buoyant, separated from the unreacted $\mathrm{UF}_{6}$ vapor cloud, and entrained with bulk air flow. If heat loss from the $\mathrm{UF}_{6}$ vapor cloud to the floor is significant, the $\mathrm{UF}_{6}$ vapor will be partially aerosolized and fall down on the floor. At the same time, the $\mathrm{UF}_{6}$ vapor cloud will experience a chemical reaction with atmospheric moisture at its surface, and thus continuously be stripped off by overlying air flow. However, in our case, the rate of $\mathrm{UF}_{6}$ vapor release is rather small, and the cloud is expected to spread widely. It is expected, therefore, that most of the released $\mathrm{UF}_{6}$ vapor get reacted with atmospheric moisture in the course of spreading and settling 
down on the floor. ${ }^{1}$ Even if a layer of $\mathrm{UF}_{6}$ vapor cloud forms on the floor, its heat transfer characteristics to the surroundings (including the floor) is very poor because of its low thermal conductivity (i.e., $0.003 \mathrm{Btu} / \mathrm{hr}$-ft-F versus 0.26 for air and 0.46 for water), timing for aerosolization of $U_{6}$ vapor due to thermal conduction/convection may be much longer than that due to its depletion caused by surface chemical reaction with atmospheric moisture. Having these in mind, the MELCOR model has been developed to capture stated-behavior of $\mathrm{UF}_{6}$ vapor upon being released. Rather than modeling the entire building, only a section of the building near the opening is modeled. Figure 4 illustrates a control volume diagram modeled with MELCOR. Flow paths between control volumes are shown as arrows in the figure. Control volumes, 111 through 115 and 102, represent volumes where $\mathrm{UF}_{6}$ vapor cloud settles, undergoes a chemical reaction with atmospheric moisture, and its reaction products, $\mathrm{UO}_{2} \mathrm{~F}_{2}$ and $\mathrm{HF}$, transport or settle on the floor. Distance from the wall to the closest autoclave is 28 feet, as can be seen in Figure 2. We assume that the area between the wall and the closest autoclave (from which we assume that $\mathrm{UF}_{6}$ vapor gets released) becomes involved in $\mathrm{UF}_{6}$ vapor settling and its chemical reaction with atmospheric moisture. Also assumed was that the $\mathrm{UF}_{6}$ vapor is released symmetrically such that the mirror region of the autoclave (i.e., another side of the autoclave away from the wall) is also involved in the $\mathrm{UF}_{6}$ vapor release. Consequently, the floor size of the control volumes, 111 through 115 and 102, was assumed to be 58' x 63'. The control volumes, 111 through 115, were modeled as thin layers with $0.4 \mathrm{~m}$ height each to provide a means to force the $\mathrm{UF}_{6}$ vapor to stay close to the floor. Even though the $\mathrm{UF}_{6}$ vapor is released at a certain height, we assume that the released $\mathrm{UF}_{6}$ vapor gets settled onto the floor immediately upon being released. Therefore, the $\mathrm{UF}_{6}$ vapor was assumed to get released into the lowest control volume, $\mathrm{cv}-111$. The $\mathrm{UF}_{6}$ vapor will fill $\mathrm{cv}-111$ first, and then react with the moisture there. Unreacted $\mathrm{UF}_{6}$ vapor will overflow to $\mathrm{cv}-112$ and react with the moisture there, and so on. Unreacted $\mathrm{UF}_{6}$ vapor is heavy cloud and very immobile. Therefore, the model assumes no direct transport of the $\mathrm{UF}_{6}$ vapor cloud from the settling control volumes (cv-111 through -115) to the environment (cv-902). Hence, no direct flow path was modeled between cv-111 through -115 and cv-902. Instead, the flow from those control volumes was modeled to pass through $\mathrm{cv}-102$ which is the upper volume of the $\mathrm{UF}_{6}$ release area, in order to transport into the environment (cv-902). The control volume 901 represents the volume of the feed building which is not affected by $\mathrm{UF}_{6}$

1 To chemically react $2 \mathrm{~kg} / \mathrm{s}$ of $\mathrm{UF}_{6}$ vapor, about $0.2 \mathrm{~kg} / \mathrm{s}$ of $\mathrm{H}_{2} \mathrm{O}$ is needed. Assuming $60 \%$ of humidity, it means that $\sim 12 \mathrm{~m}^{3} / \mathrm{s}$ of air is needed to completely react. If $\mathrm{UF}_{6}$ vapor spreads over $12 \mathrm{~m}^{2}$ area $(\sim 2 \mathrm{~m}$ radius) assuming $1 \mathrm{~m} / \mathrm{s}$ of air velocity, it will be completely reacted before it spreads down onto the floor. This is a conservative assumption and was made since we have not conducted a spreading assessment. 
vapor release and transport. This volume provides air into the control volumes where the released $\mathrm{UF}_{6}$ vapor transport occurs. To bound the problem, two values of wind speed were considered. The conservative first case assumed a constant wind velocity of $\sim 1 \mathrm{~m} / \mathrm{s}$ (200 fpm). Consequently, air was assumed to blow into the building through the train and crane openings at $1 \mathrm{~m} / \mathrm{s}(200 \mathrm{fpm})$. Since air flow area increases from the opening size (23' $\times 20^{\prime}$ 'for train door and 9.3' $\times 58.8^{\prime}$ for crane door) to total building cross section area (63'x43.3') before the air enters the affected control volumes, $1 \mathrm{~m} / \mathrm{s}(200 \mathrm{fpm})$ of velocity was scaled down to $0.36 \mathrm{~m} / \mathrm{s}$ (72 fpm) of velocity for flow paths from cv-901 to cv-111 through -115 and -102 . The second case assumed a low (close to stagnant) wind speed of $\sim 1 \mathrm{~cm} / \mathrm{s}(2 \mathrm{fpm})$.

Aerosols in the current study need to be characterized and specified in MELCOR input for the aerosol transport calculations with consideration of aerosol growth by agglomeration, condensation, etc. Aerosol size is assumed to be a log-normal distribution between $0.4 \mu \mathrm{m}$ and $2.5 \mu \mathrm{m}$ diameter. In the current model, the aerosol size range is binned into five sections, and in each section, one aerosol component is assumed to represent aerosols in that section since we have a single component aerosol $\left(\mathrm{UO}_{2} \mathrm{~F}_{2}\right)$ in the current study. Also assumed was 1.85 for the dynamic shape factor and 2.25 for the agglomeration shape factor. For aerosol particle density, $6,375 \mathrm{~kg} / \mathrm{m}^{3}$ was used for the current study.

\section{RESULTS AND ANALYSIS}

The MELCOR model was executed for the $\mathrm{UF}_{6}$ vapor release (from $100 \mathrm{~s}$ until $400 \mathrm{~s}$ representing a $5 \mathrm{~min}$ release duration, as depicted in Figure 3) until 1000s into transient. First 100 s before the $\mathrm{UF}_{6}$ release was necessary to establish a steady-state condition. Results for this 5 min release case are shown in Figures 5 through 12.

Figure 5 shows atmospheric temperature variations of affected control volumes. The control volume 111 is exposed to sensible energy carried by the released $U_{6}$ vapor (about $240 \mathrm{~F}$ ) and to chemical reaction energy (about $0.32 \mathrm{MJ} / \mathrm{kg}$ of $\mathrm{UF}_{6}$ reacted). As seen in the figure, atmospheric temperature of $\mathrm{cv}-111$ that is the volume into which the $\mathrm{UF}_{6}$ vapor is released, is highest, $\sim 520 \mathrm{~F}$ during the $\mathrm{UF}_{6}$ release period. The control volume, $\mathrm{cv}-102$, is seen not to be affected much by the $\mathrm{UF}_{6}$ vapor release. Its temperature increase (very slight in magnitude) is mainly due to air convection. Figure 6 illustrates mass flow rates between the affected control volumes. Numbers in the legend box represent control volume index. 
As seen in the figure, flow rates as going up through the upper control volumes, increase since the upper control volume has more flow as air coming in from cv-901 in addition to air/vapor/aerosol mixture flowing from the lower control volume. Mass reaction rates of the $\mathrm{UF}_{6}$ vapor with atmospheric moisture in various control volumes are shown in Figure 7. The control volume 111 has the highest $\mathrm{UF}_{6}$ reaction rate since the $\mathrm{UF}_{6}$ vapor is released into this particular volume. Almost no $\mathrm{UF}_{6}$ reaction is seen in $\mathrm{cv}-102$. Figure 8 shows variations of vapor and aerosols released from the feed building to the environment. The $\mathrm{UF}_{6}$ release magnitude is almost zero. About $320 \mathrm{~kg}$ of $\mathrm{UO}_{2} \mathrm{~F}_{2}$ aerosol and $\sim 125 \mathrm{~kg}$ of $\mathrm{HF}$ vapor were predicted to be released into the environment. These numbers represent $\sim 66 \%$ of all $\mathrm{UO}_{2} \mathrm{~F}_{2}$ aerosol mass and $\sim 100 \%$ of $\mathrm{HF}$ mass produced from the chemical reaction between the $\mathrm{UF}_{6}$ vapor and the atmospheric moisture. Figure 9 illustrates variation of $\mathrm{UF}_{6}$ vapor mass in various control volumes at the end of each time step. Variations of $\mathrm{UO}_{2} \mathrm{~F}_{2}$ aerosol mass and the $\mathrm{UO}_{2} \mathrm{~F}_{2}$ mass settled in various locations are shown in Figure 10 and 11 , respectively. Because aerosols are advected to $\mathrm{cv}-102$ from the lower control volumes (cv-111 through cv-115), cv-102 was predicted to contain a substantial amount of the $\mathrm{UO}_{2} \mathrm{~F}_{2}$ aerosols before the aerosol magnitude diminishes due to the release into the environment. Figure 11 shows aerosol deposition onto the floor. Aerosols settle due to gravity onto the floor or fall out once they grow to reach a critical size (in the current study, 2.5 $\mu \mathrm{m}$ diameter is the maximum aerosol size as explained in the previous chapter). Figure 12 shows the variation of HF mass distribution in various locations. Again the vapor is advected from the lower control volumes into the upper one, $\mathrm{cv}-102$ was predicted to contain substantial amount of the vapor before the HF vapor gets released into the environment.

To examine the effect of stagnant (or very stable) atmospheric condition for the $\mathrm{UF}_{6}$ release accident, another MELCOR run was executed for the same $\mathrm{UF}_{6}$ release scenario but with 1 $\mathrm{cm} / \mathrm{s}$ ( $2 \mathrm{fpm}$ ) of far-field wind velocity. The results are presented in Figures 13 through 19 for the transient until 7,000s. Because of the very weak air flow, the atmospheric temperature of $\mathrm{cv}-111$ where the $\mathrm{UF}_{6}$ vapor gets released, increases up to $850 \mathrm{~K}$. It is shown in Figure 15, that a negligible amount of $\mathrm{UO}_{2} \mathrm{~F}_{2}(\sim 4 \mathrm{~kg})$ was predicted to be released into the environment. In the same figure, $\mathrm{HF}$ is shown to keep being released into the environment, and expected to do so until all available HF mass is completely released into the environment. 


\section{CONCLUSION}

The $\mathrm{UF}_{6}$ vapor was assumed to be released through a 0.875 "-dia broken valve fitting on a pigtail from the cylinder in the feed facility, X-343, of the Portsmouth Gaseous Diffusion Plant. The release rate was predicted using the CYLIND code, to be about $1.7 \sim 2 \mathrm{~kg} / \mathrm{s}$ over a 5-min period. The MELCOR model was developed to calculate the $\mathrm{UF}_{6}$ behavior, its reaction with the atmospheric moisture, transport and settling of its reaction products, $\mathrm{UO}_{2} \mathrm{~F}_{2}$ and $\mathrm{HF}$, and the source term magnitude. Flow paths between control volumes were modeled carefully to capture possible air flow patterns. A conservative value of $1 \mathrm{~m} / \mathrm{s}(200$ fpm) of wind velocity at far-field was scaled to $0.36 \mathrm{~m} / \mathrm{s}$ at the entrance of each control volume based on air mass flow conservation. Assuming instantaneous spreading of the released $\mathrm{UF}_{6}$ vapor on the floor where released and also a constant availability of outside wind flow of $1 \mathrm{~m} / \mathrm{s}$, the model predicted that $100 \%$ of the $\mathrm{UF}_{6}$ vapor reacts with the moisture, $\sim 66 \%$ of $\mathrm{UO}_{2} \mathrm{~F}_{2}$ and $\sim 100 \%$ of $\mathrm{HF}$ are predicted to be released over $\sim 10$ minutes into the environment if the doors (train and crane access doors) do not shut. When the farfield wind velocity was assumed to be $1 \mathrm{~cm} / \mathrm{s}(2 \mathrm{fpm})$, almost none of the aerosols were predicted to be released into the environment, and $H F$ vapor was predicted to be released over a long period of time.

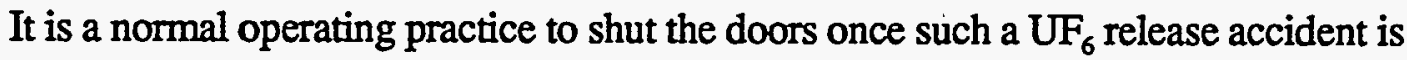
recognized. Assuming that the doors shut within 5 minutes (as may be reasonably expected), the source term amount will likely be reduced substantially such that even with 1 $\mathrm{m} / \mathrm{s}\left(200 \mathrm{fpm}\right.$ ) wind speed, $\sim 70 \%$ of $\mathrm{UO}_{2} \mathrm{~F}_{2}$ aerosols and $\sim 50 \%$ of $\mathrm{HF}$ are retained within the feed facility building. Again, if only limited $\mathrm{UF}_{6}$ vapor spreading takes place, the degree of the chemical reaction will also be limited and the releases will take place over longer period of time, thereby, providing more time for accident mitigation and containment. 


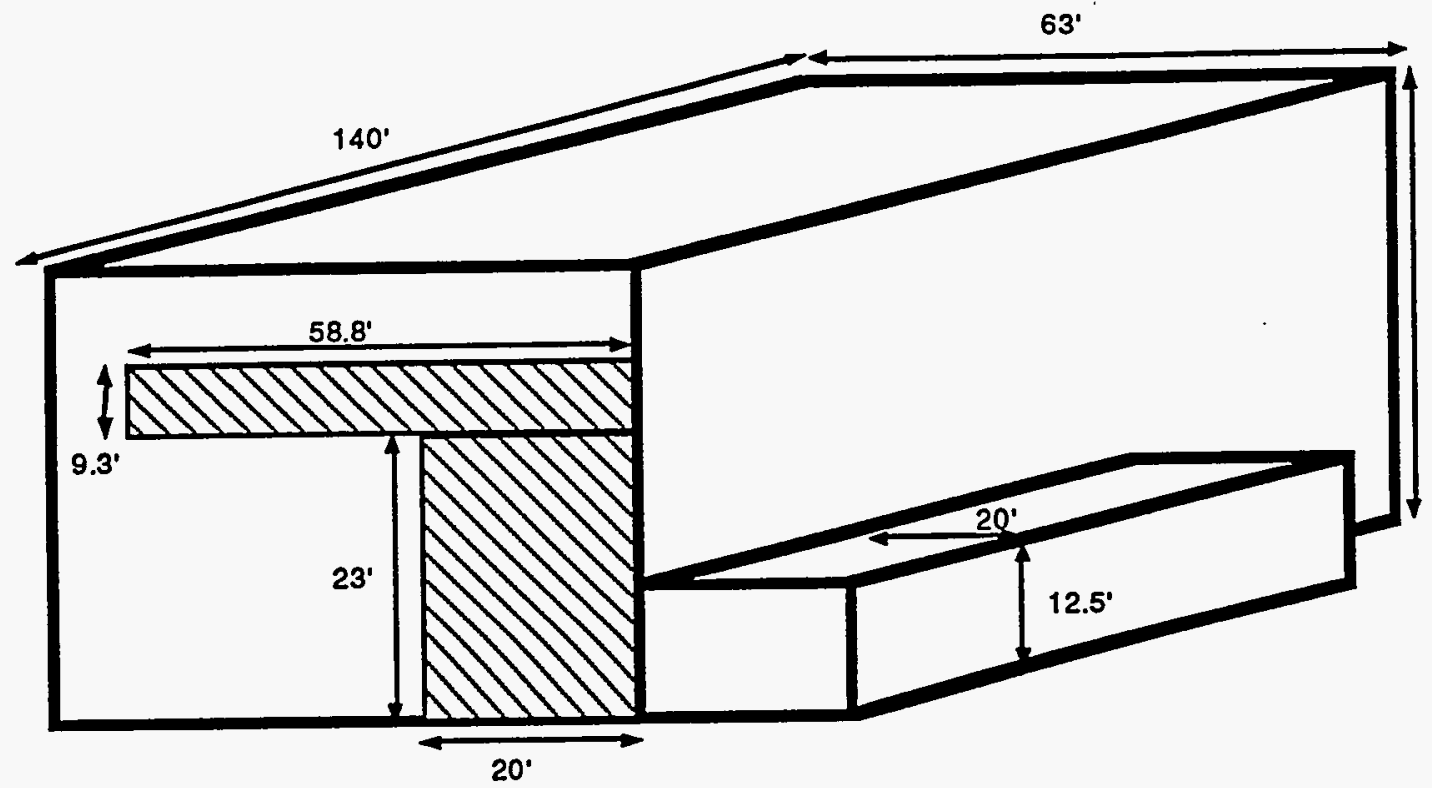

Figure 1. A Schematics of Feed Facility Building, X-343, of the Portsmouth GDP

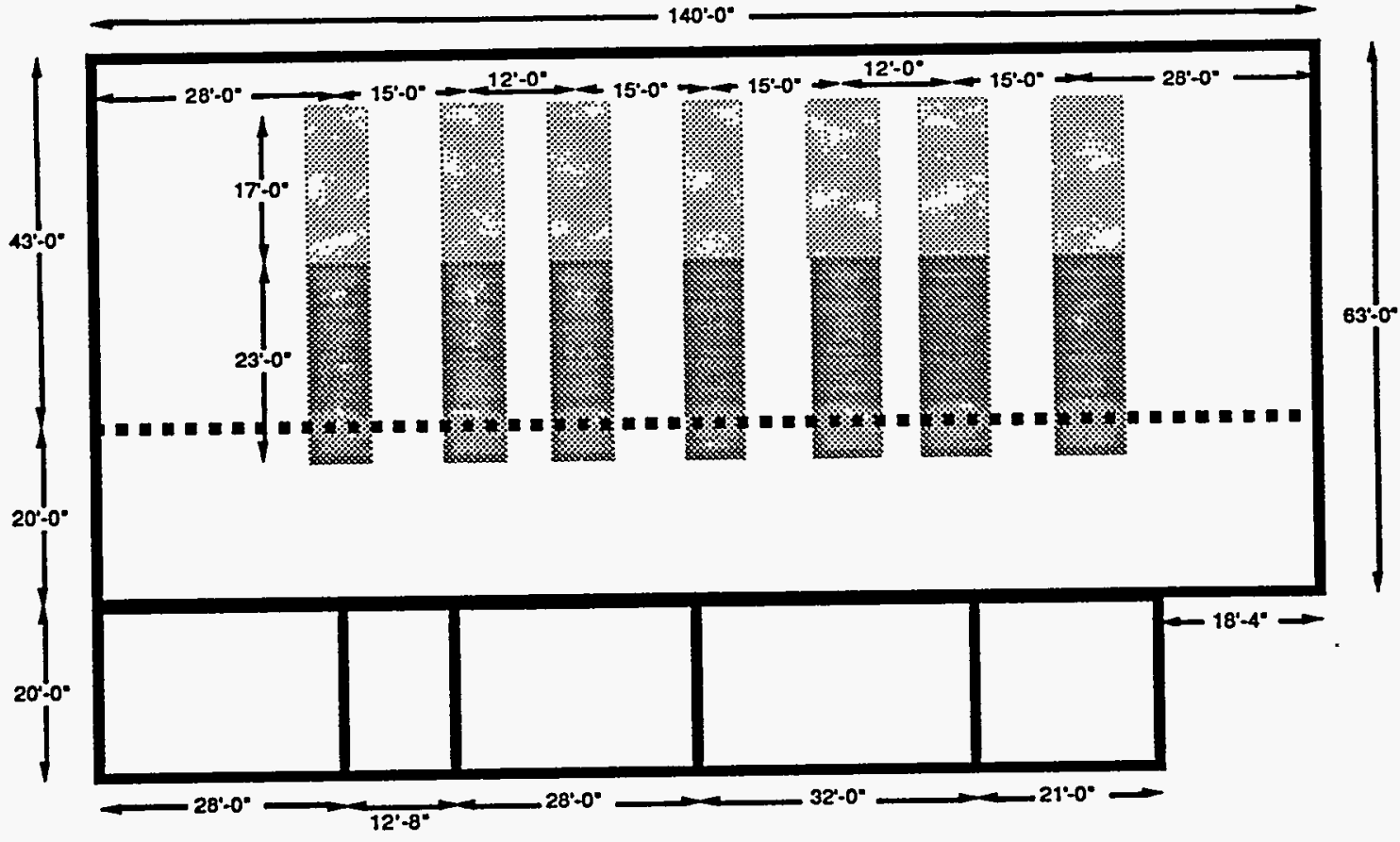

Figure 2. Simplified Plan View Drawing of X-343 of the Porthmouth GDP 


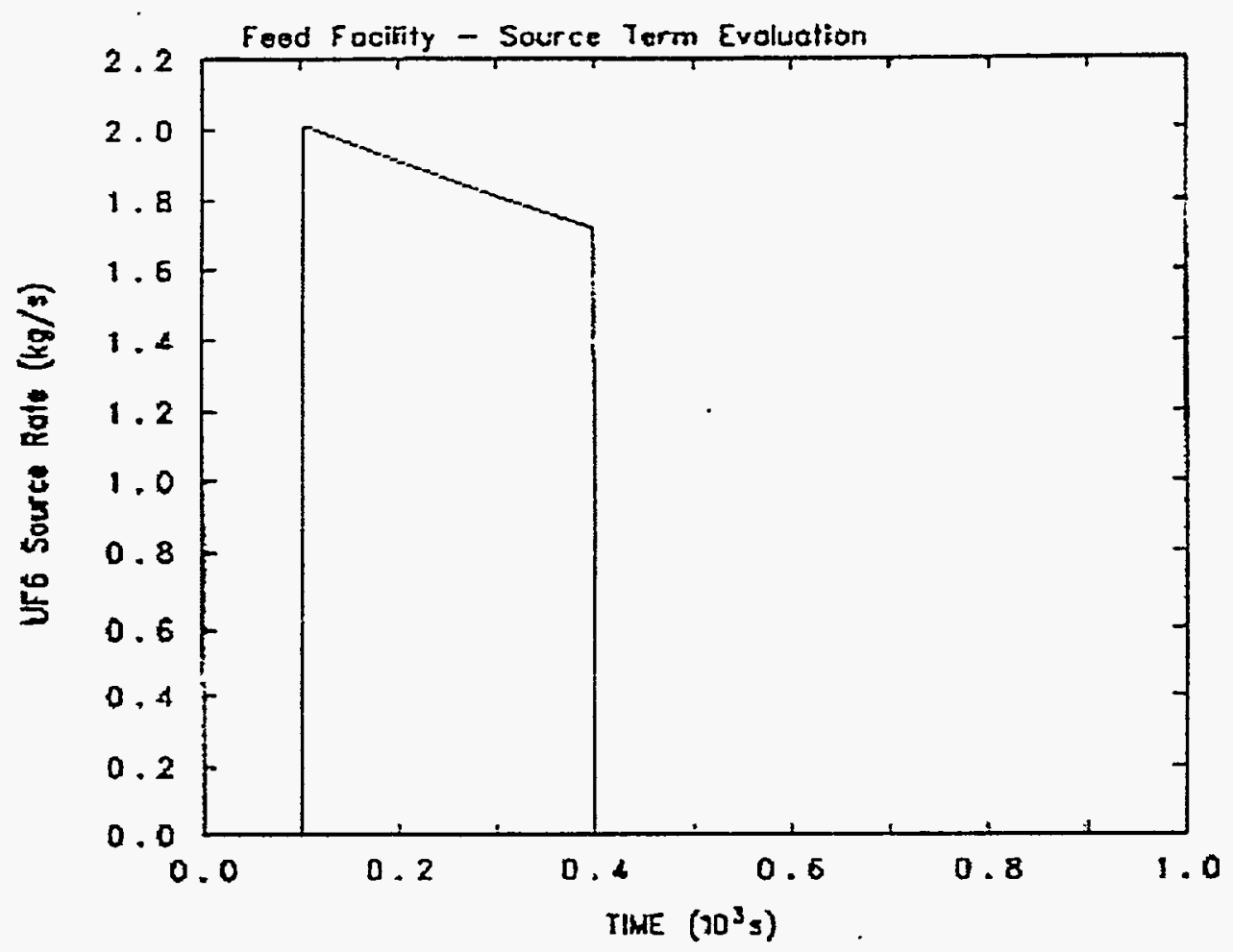

Figure 3. Mass Rate of $\mathrm{UF}_{6}$ Vapor Released into the X-343 Feed Facility

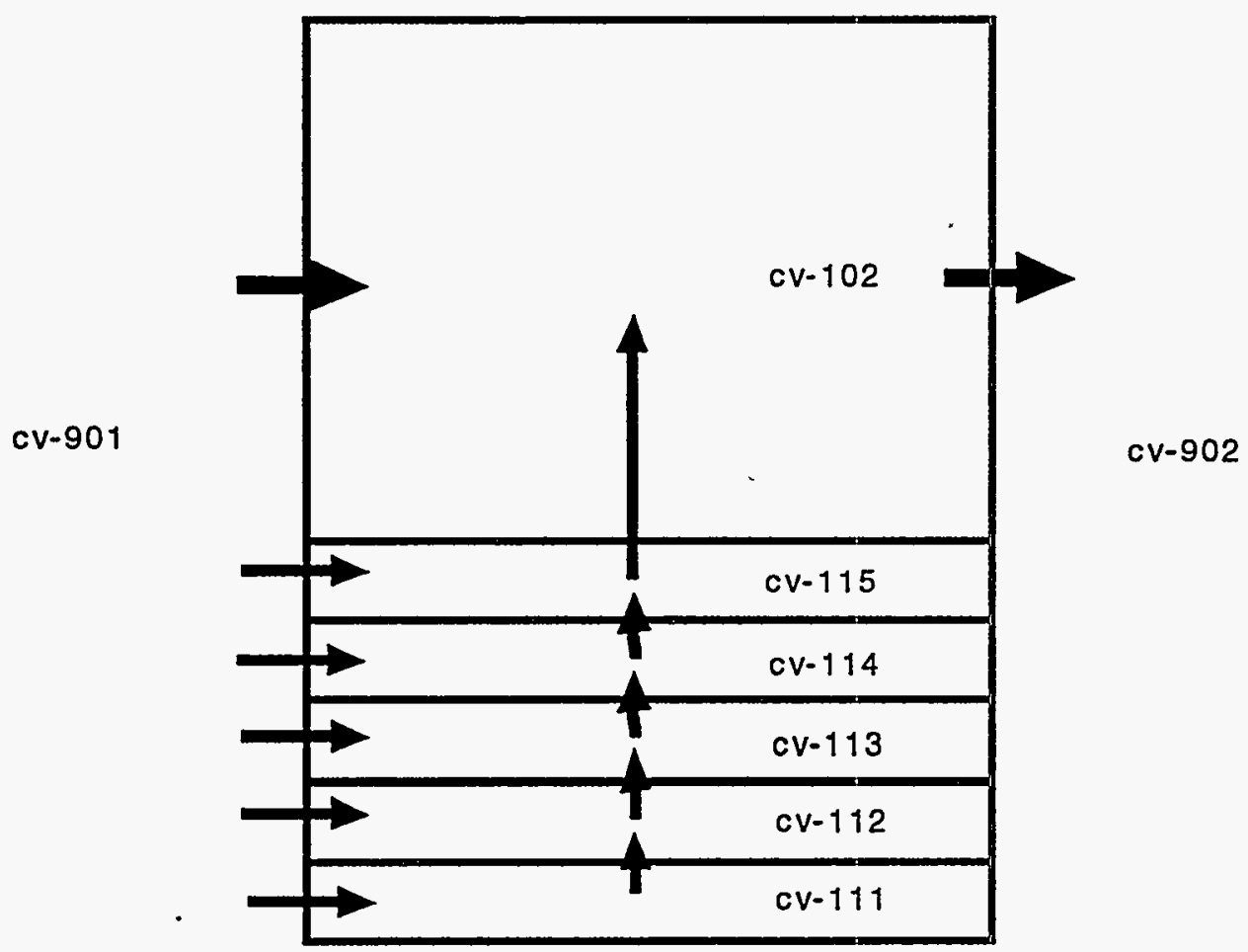

Figure 4. MELCOR Nodalization for Source Term Evaluation from Feed Facility 


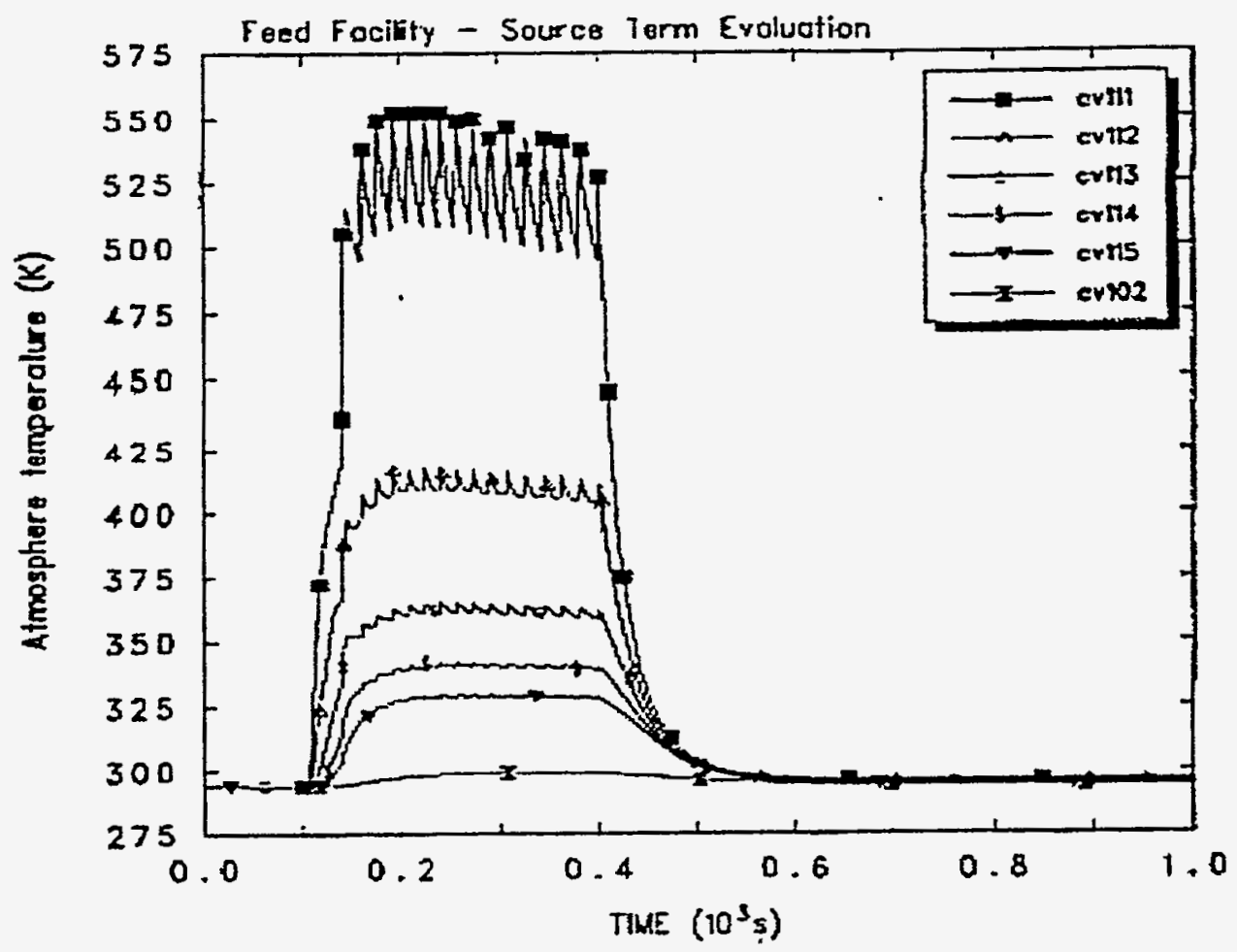

Figure 5. Variation of Average Temperature of Control Volumes (far-field wind velocity $=1 \mathrm{~m} / \mathrm{s}$ )

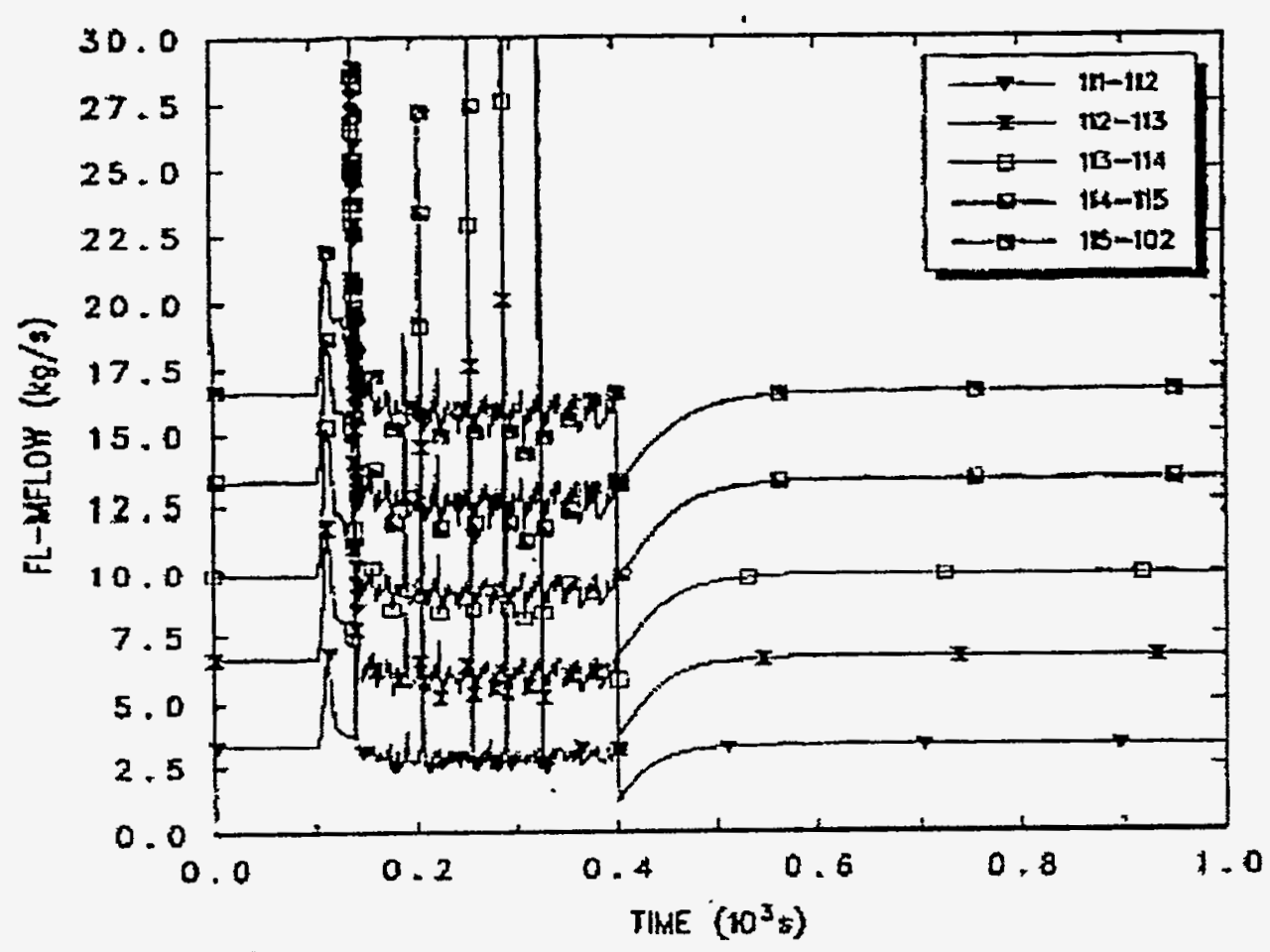

Figure 6. Mass Flow Rates Between Control Volumes

(Numbers in Legend Box Indicate Control Volumes) (far-field wind velocity $=1 \mathrm{~m} / \mathrm{s}$ )) 


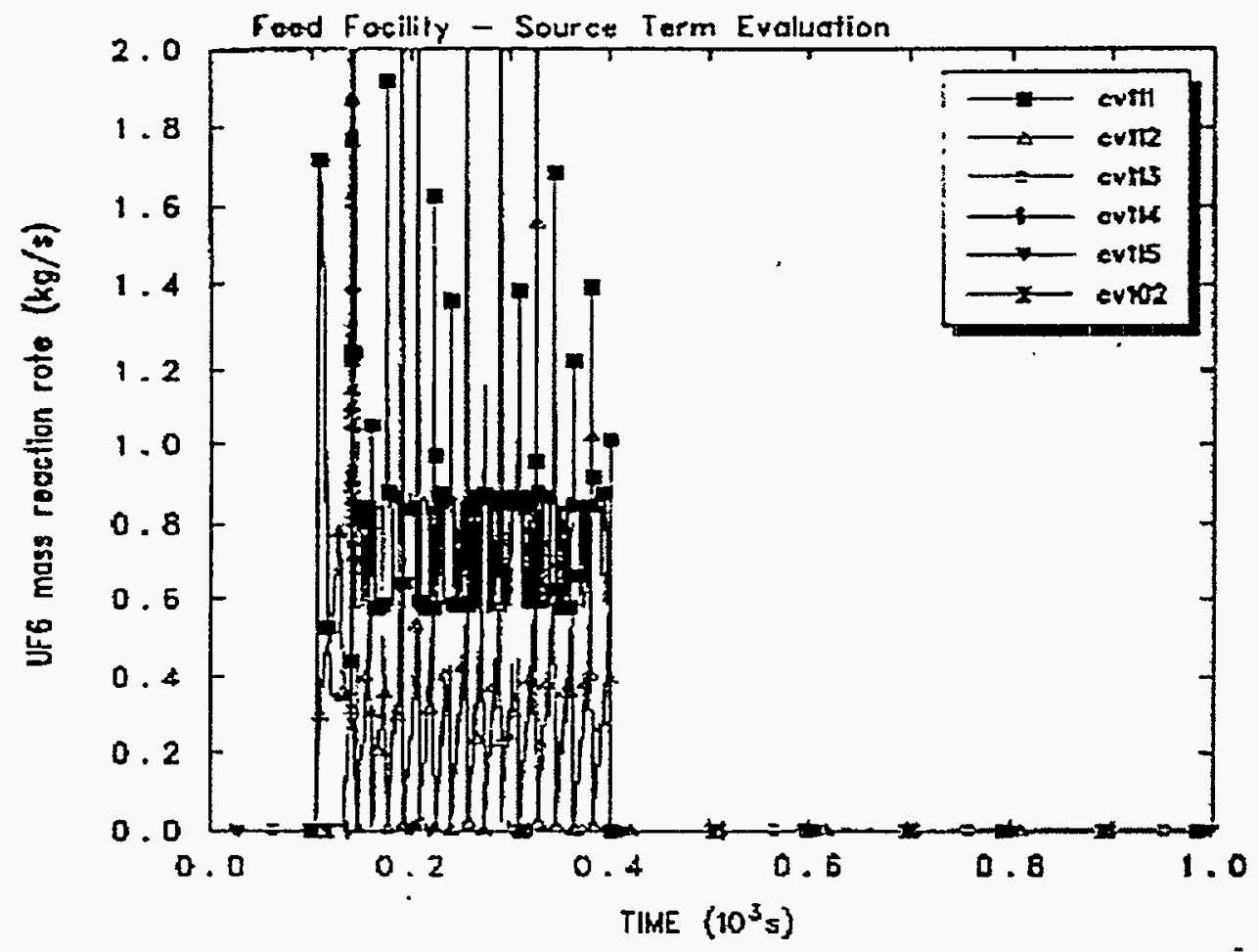

Figure 7. Mass Reaction Rate of $\mathrm{UF}_{6}$ Vapor and Atmospheric Moisture in Various Control Volumes (far-field wind velocity $=1 \mathrm{~m} / \mathrm{s}$ )

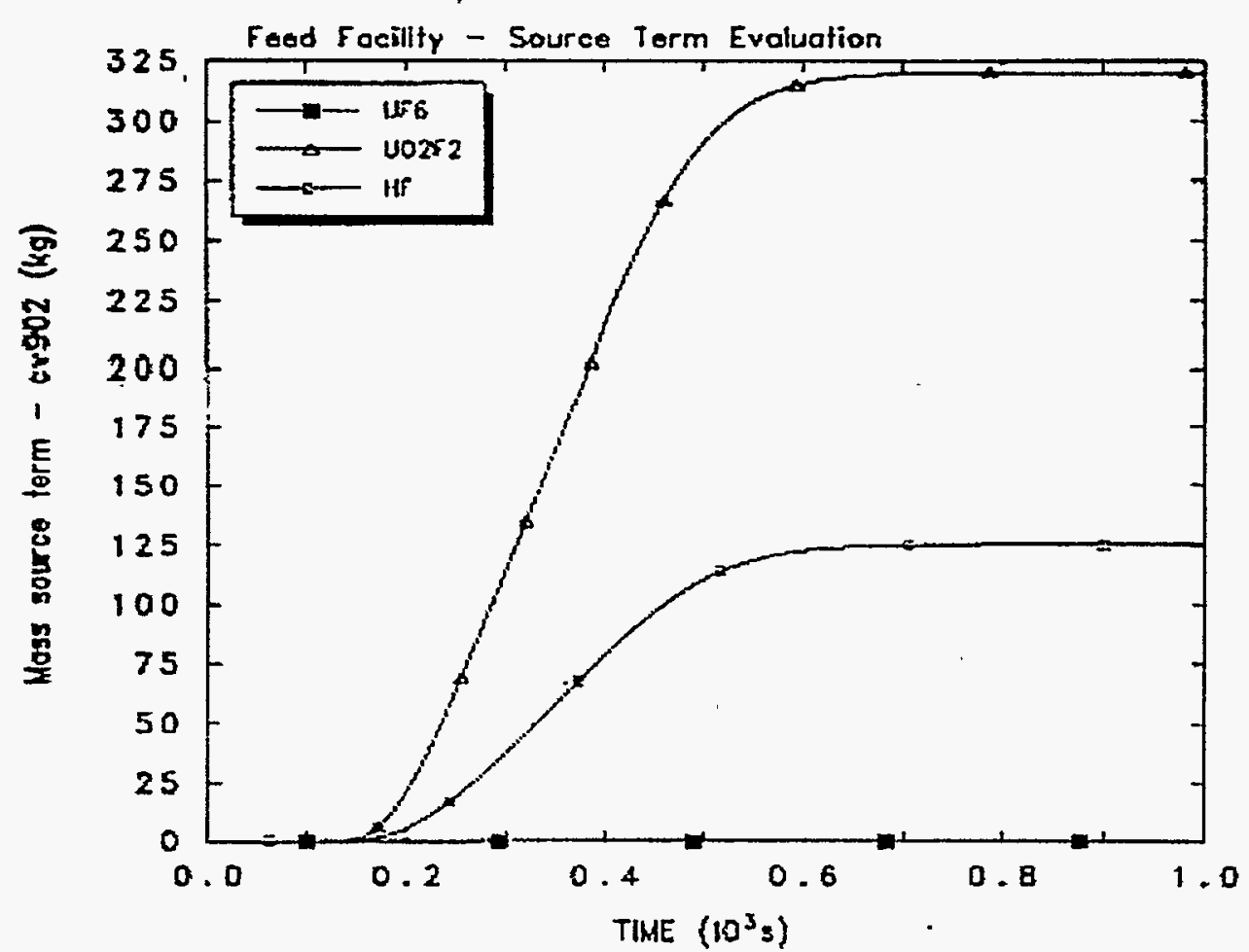

Figure 8. Mass Source Term of $\mathrm{UO}_{2} \mathrm{~F}_{2}, \mathrm{HF}$ and $\mathrm{UF}_{6}$ Released into the Environment (far-field wind velocity $=1 \mathrm{~m} / \mathrm{s}$ ) 


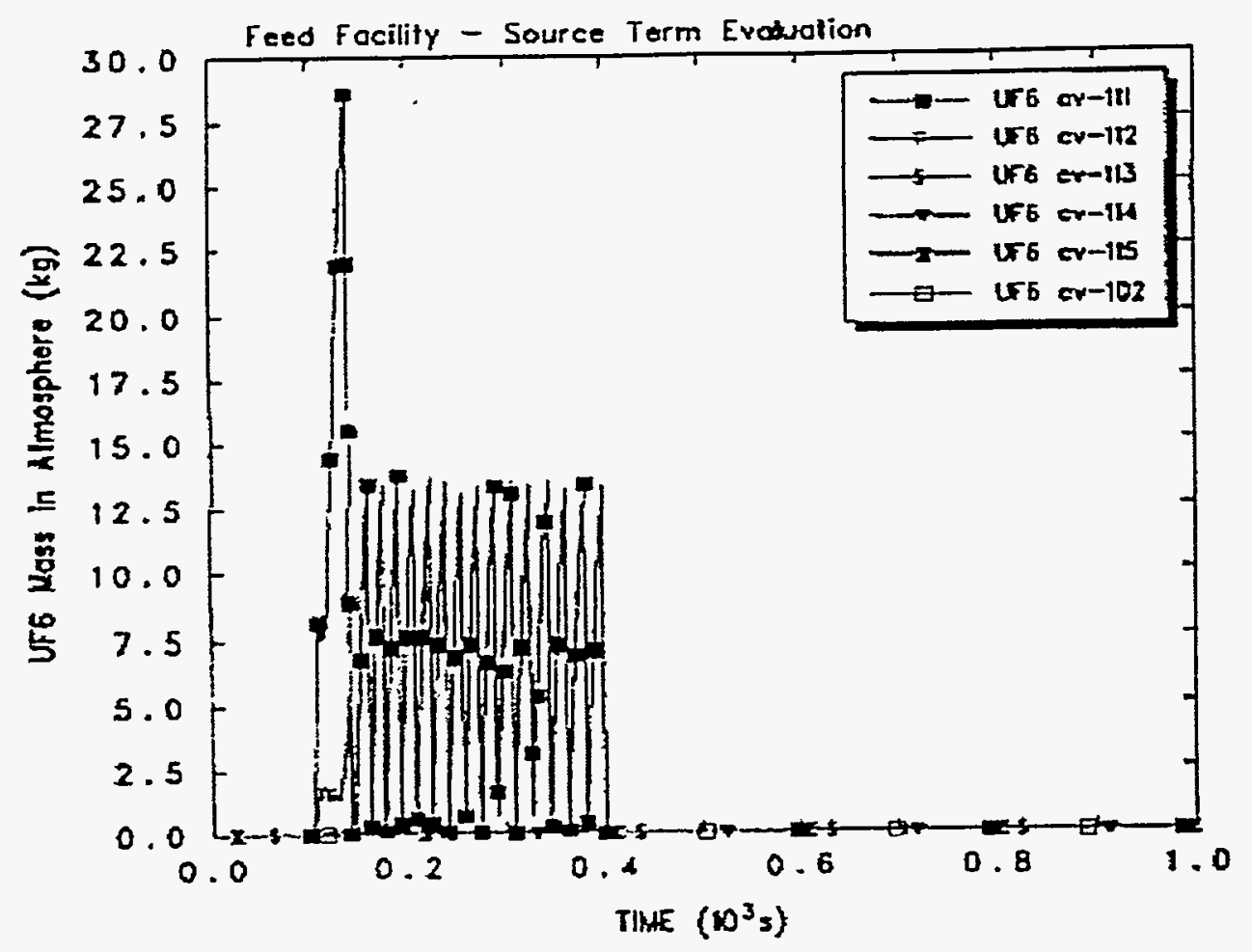

Figure 9. $\mathrm{UF}_{6}$ Vapor Mass Variation at the End of Each Time Step (far-field wind velocity $=1 \mathrm{~m} / \mathrm{s}$ )

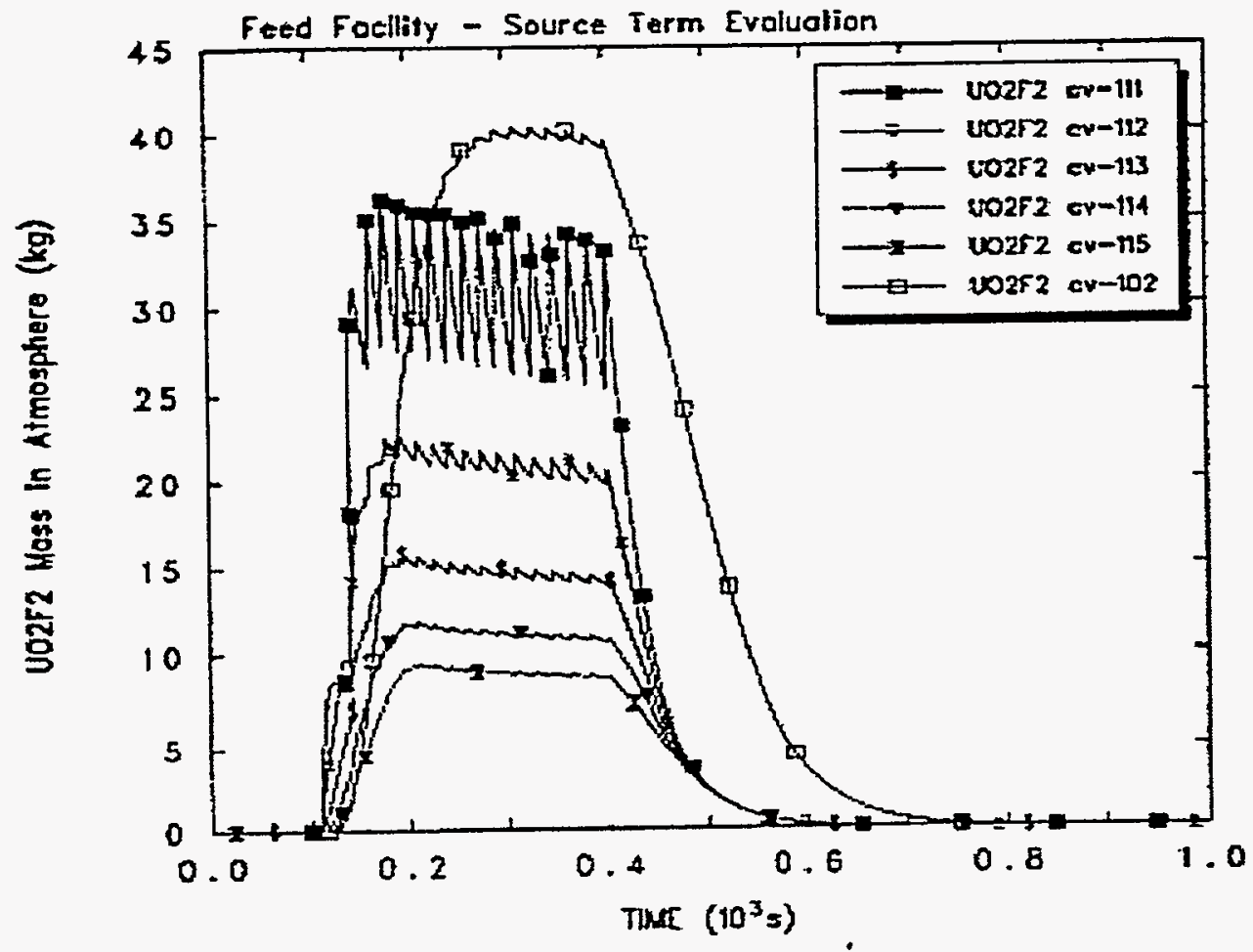

Figure 10. $\mathrm{UO}_{2} \mathrm{~F}_{2}$ Mass Variation in Various Control Volume Atmosphere . (far-field wind velocity $=1 \mathrm{~m} / \mathrm{s}$ ) 


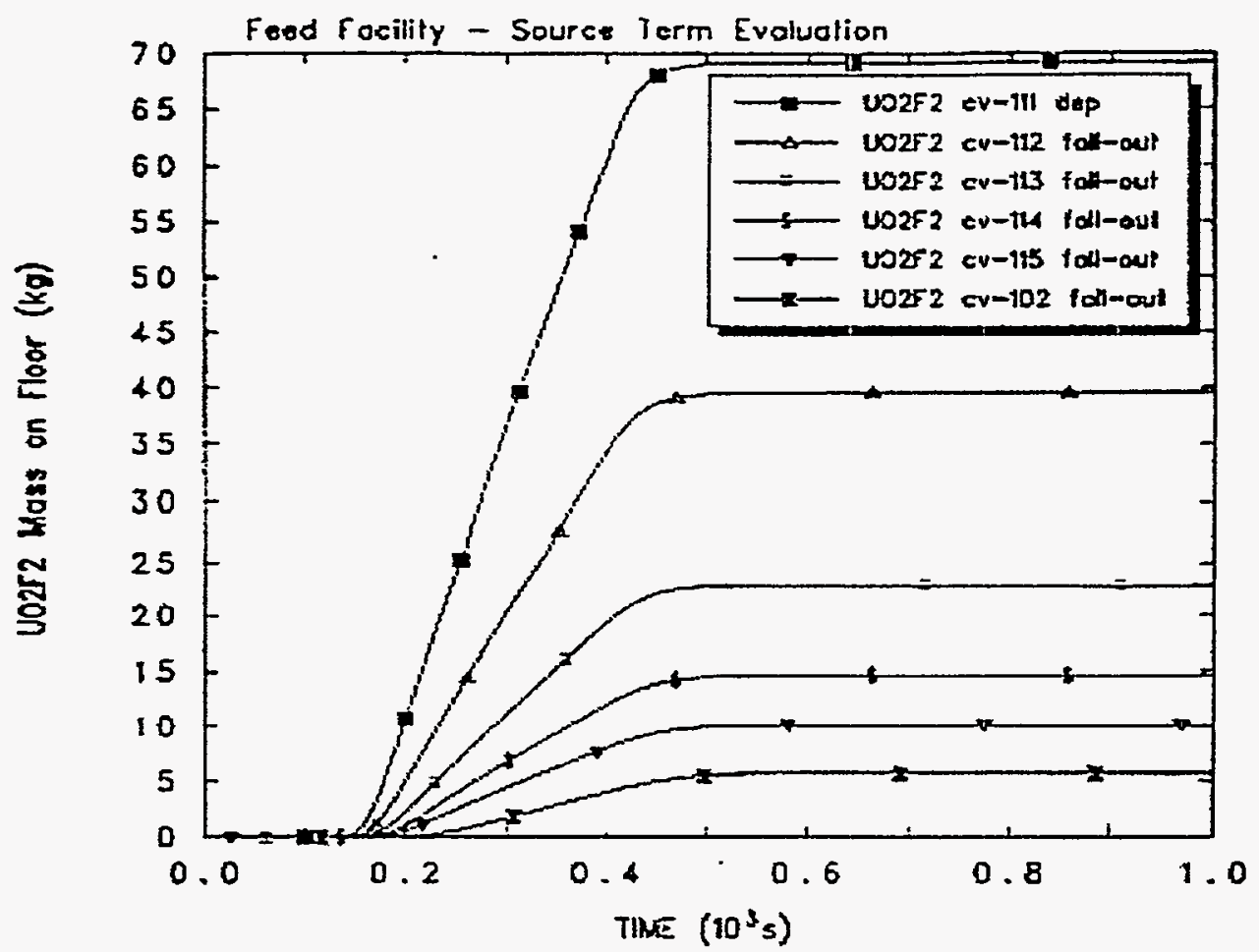

Figure 11. Mass of $\mathrm{UO}_{2} \mathrm{~F}_{2}$ Aerosol Settled or Fall-out onto the Floor from Each Control Volume (far-field wind velocity $=1 \mathrm{~m} / \mathrm{s}$ )

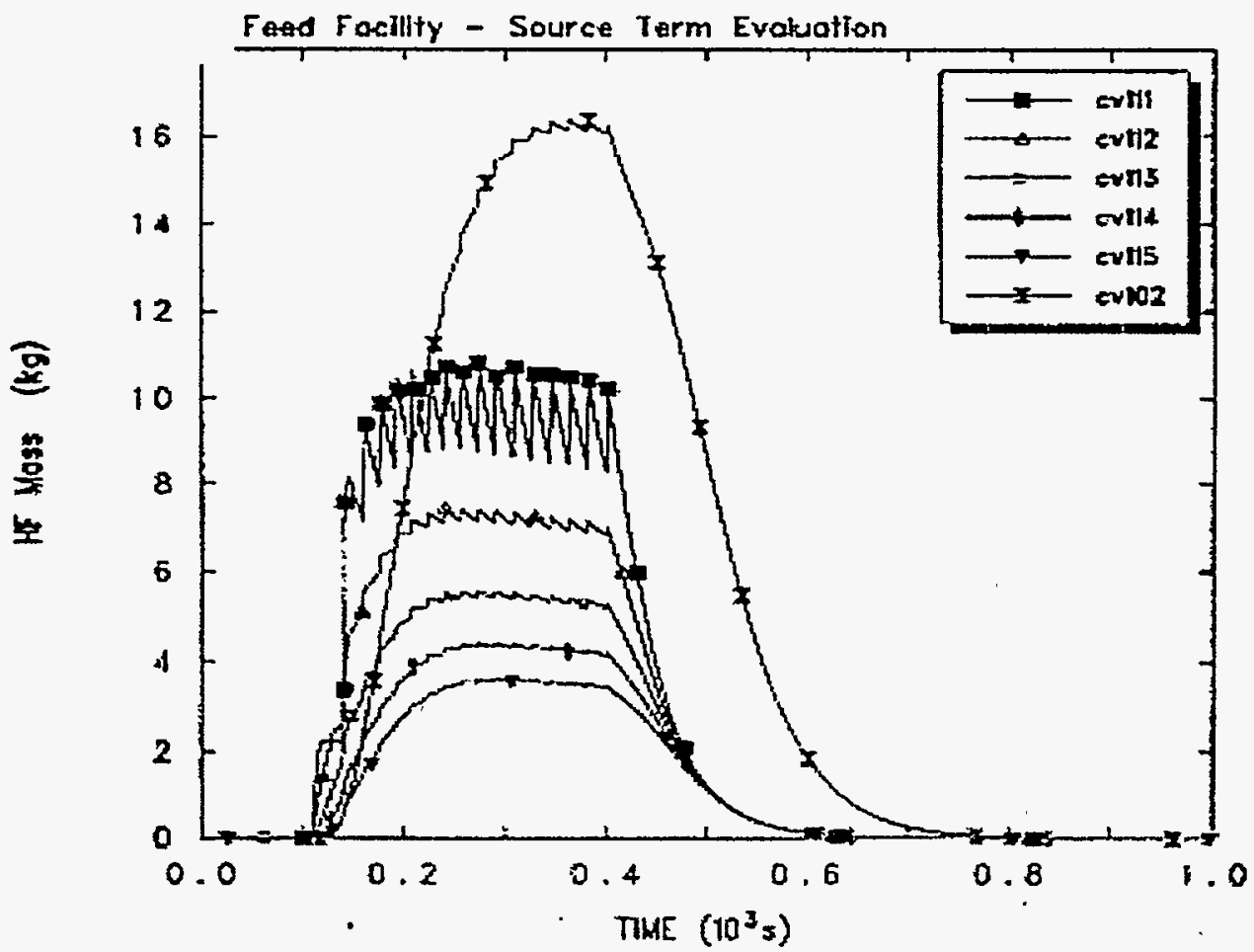

Figure 12. HF Mass Variations in Control Volumes (far-field wind velocity $=1 \mathrm{~m} / \mathrm{s}$ ) 


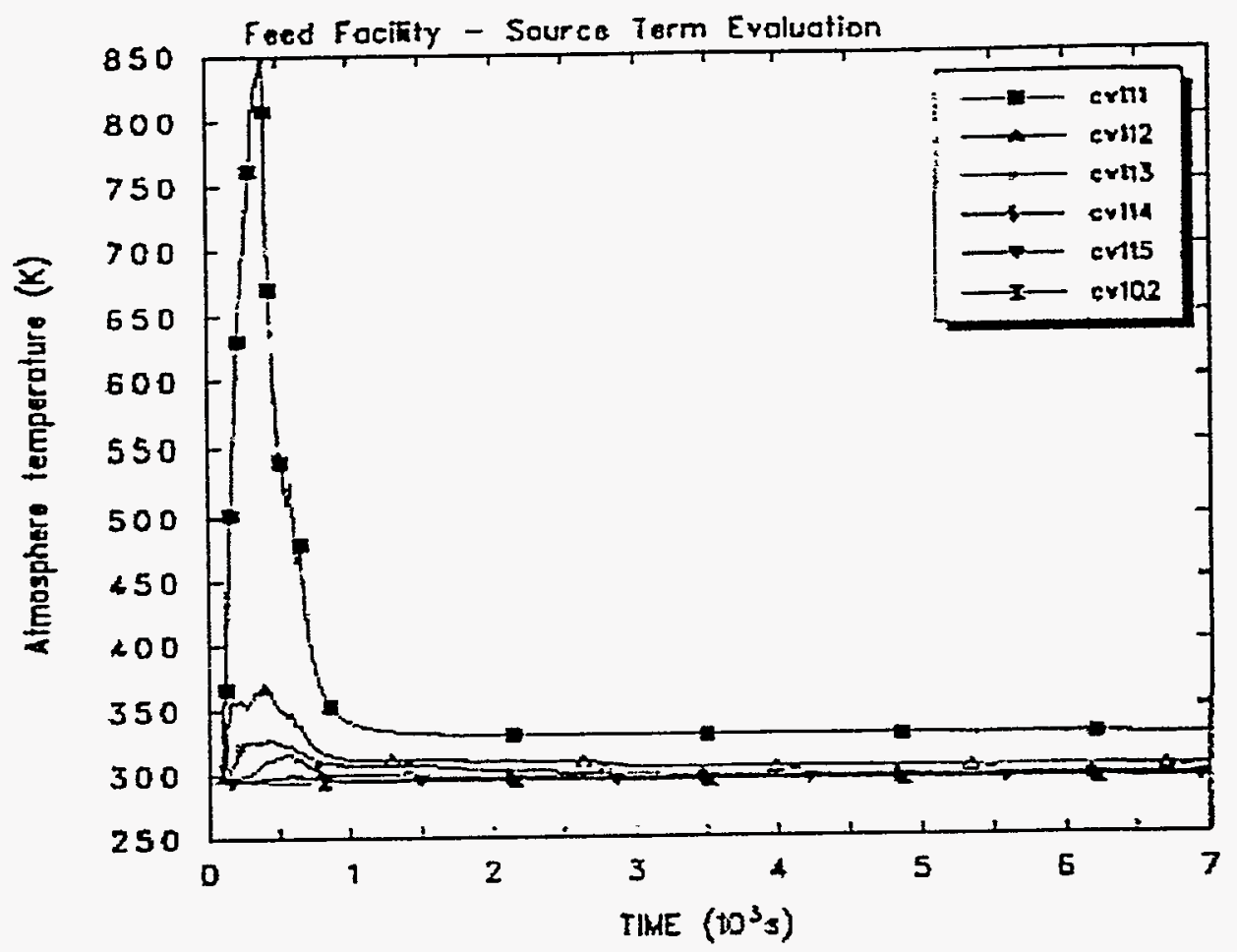

Figure 13. Variation of Average Temperature of Control Volumes (far-field wind velocity $=1 \mathrm{~cm} / \mathrm{s}$ )

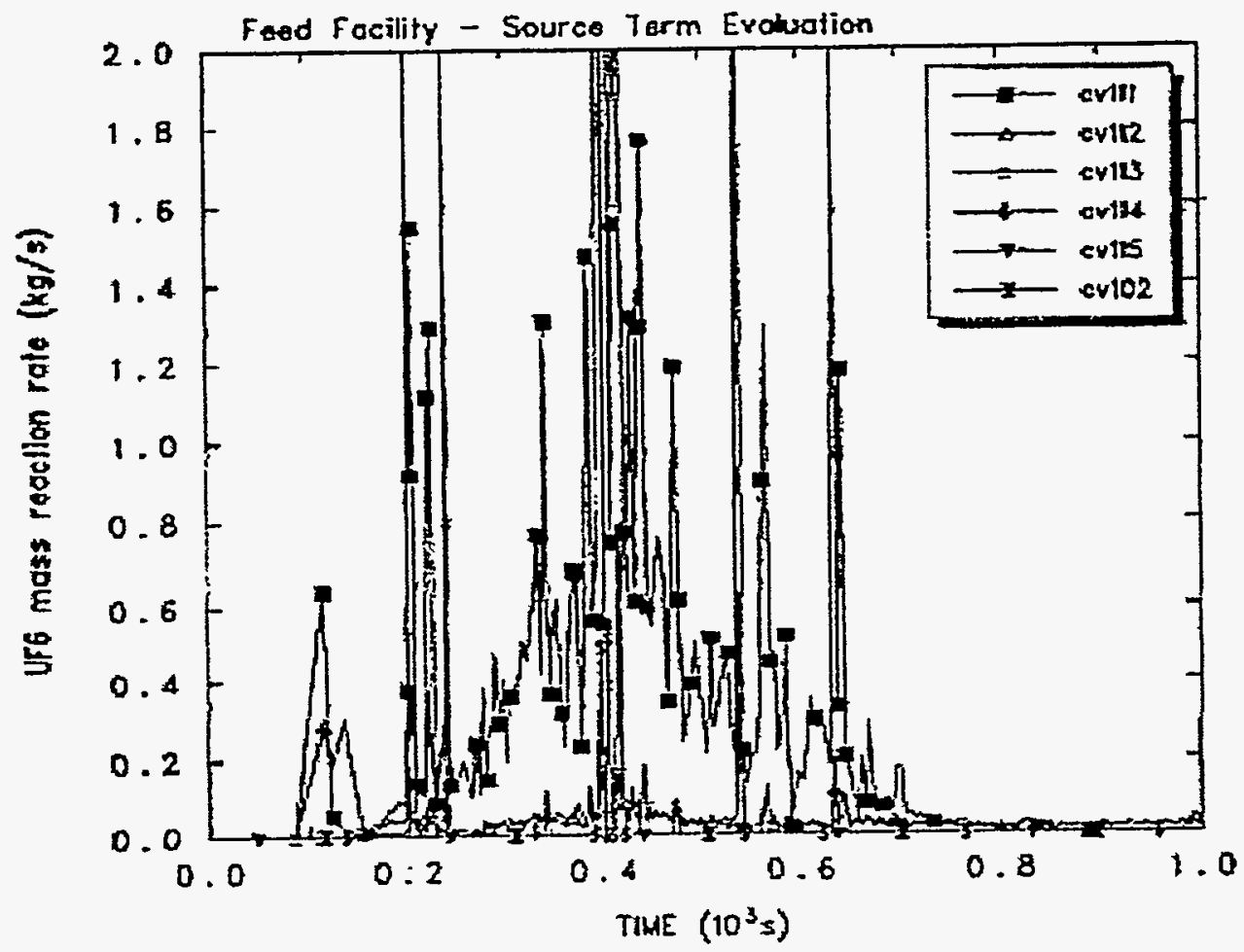

Figure 14. Mass Reaction Rate of $\mathrm{UF}_{6}$ Vapor and Atmospheric Moisture in Various Control Volumes (far-field wind velocity $=1 \mathrm{~cm} / \mathrm{s}$ ) 


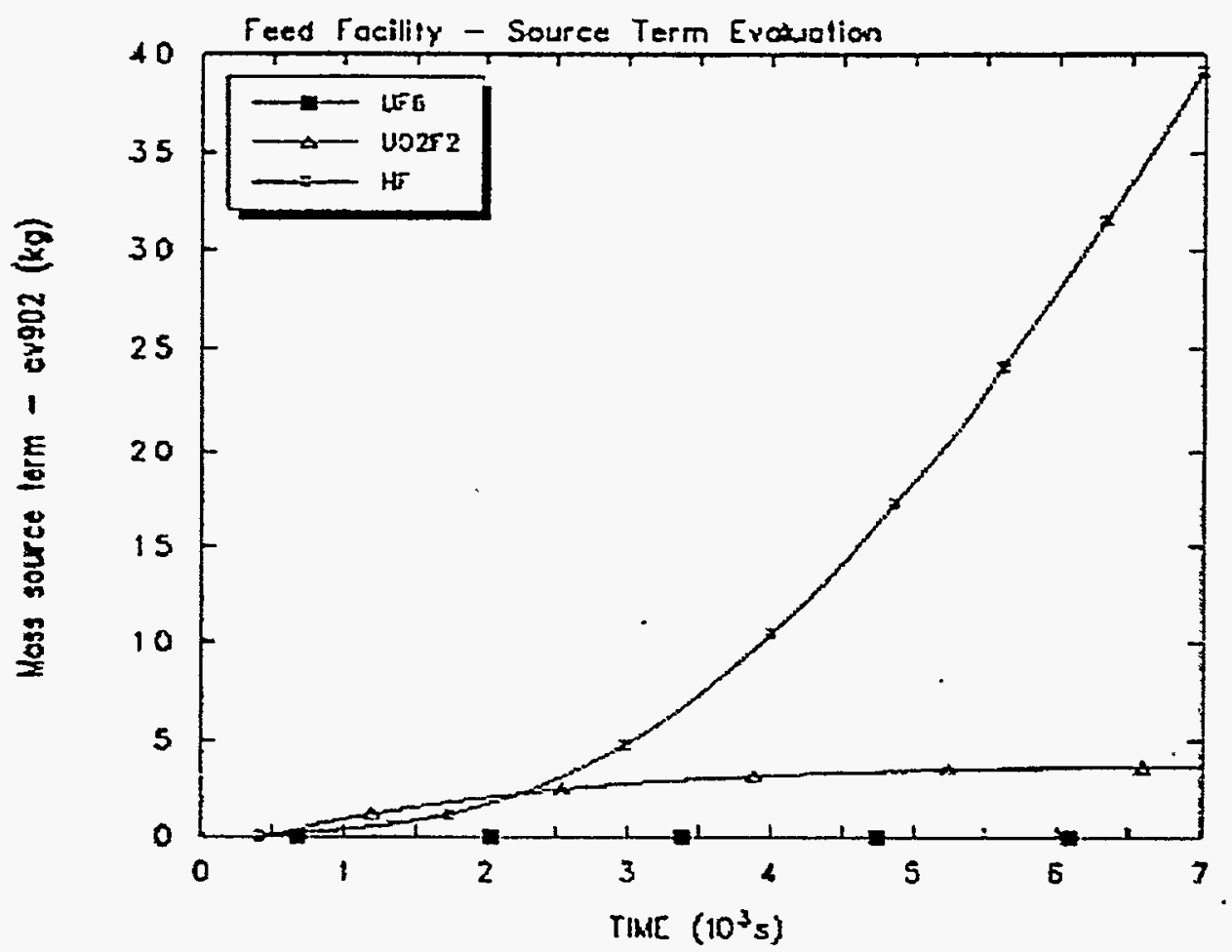

Figure 15. Mass Source Term of $\mathrm{UO}_{2} \mathrm{~F}_{2}, \mathrm{HF}$ and $\mathrm{UF}_{6}$ Released into the Environment (far-field wind velocity $=1 \mathrm{~cm} / \mathrm{s}$ )

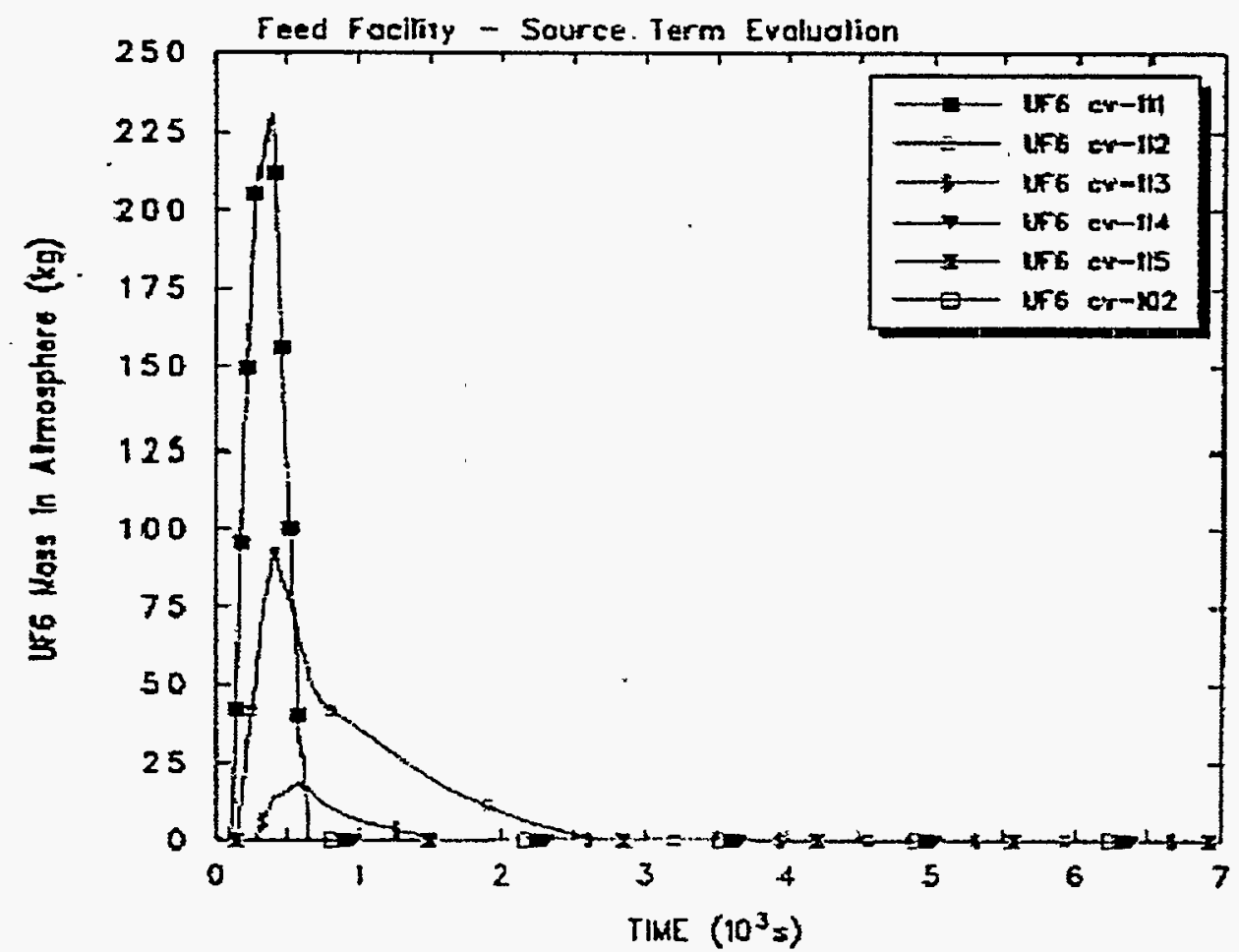

Figure 16. $\mathrm{UF}_{6}$ Vapor Mass Variation at the End of Each Time Step (far-field wind velocity $=1 \mathrm{~cm} / \mathrm{s}$ ) 


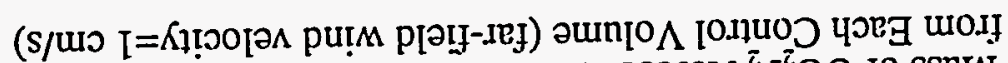

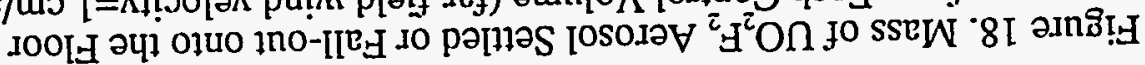

$\left({ }_{\mathrm{r}} \mathrm{Ob}\right)$ IसII

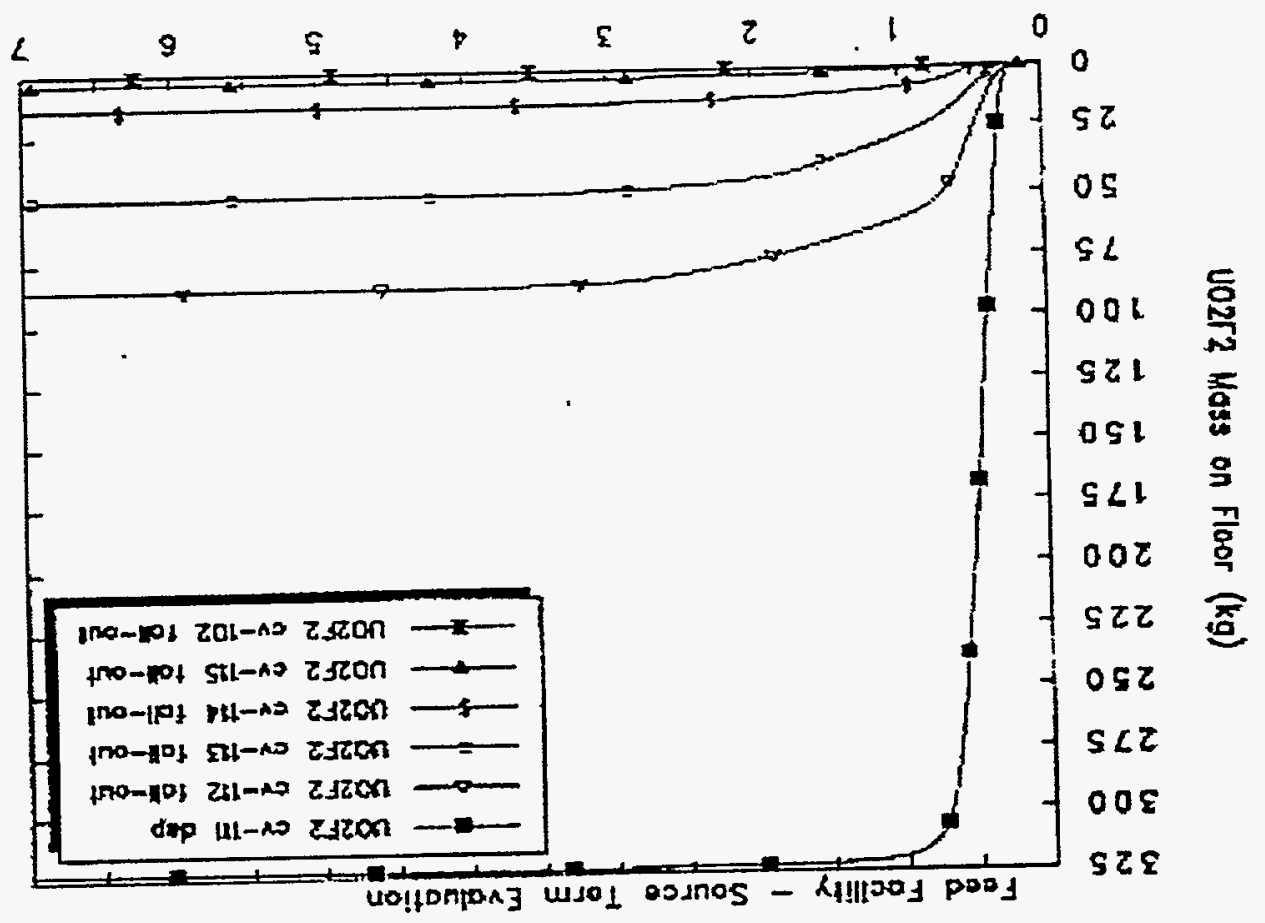

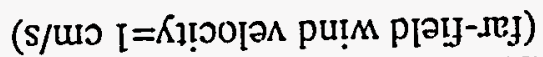

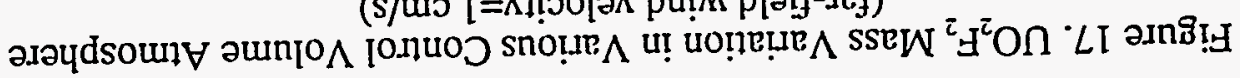

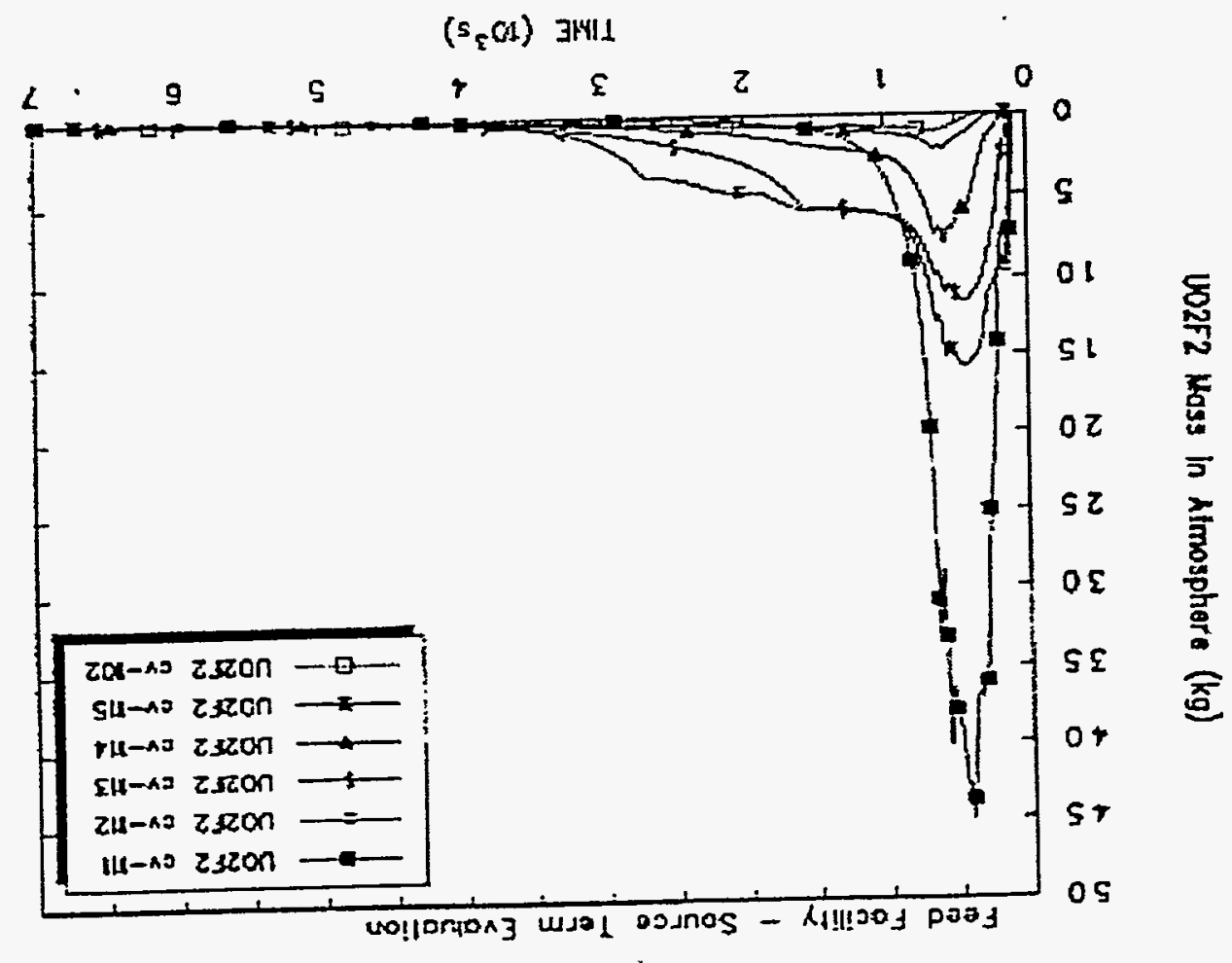




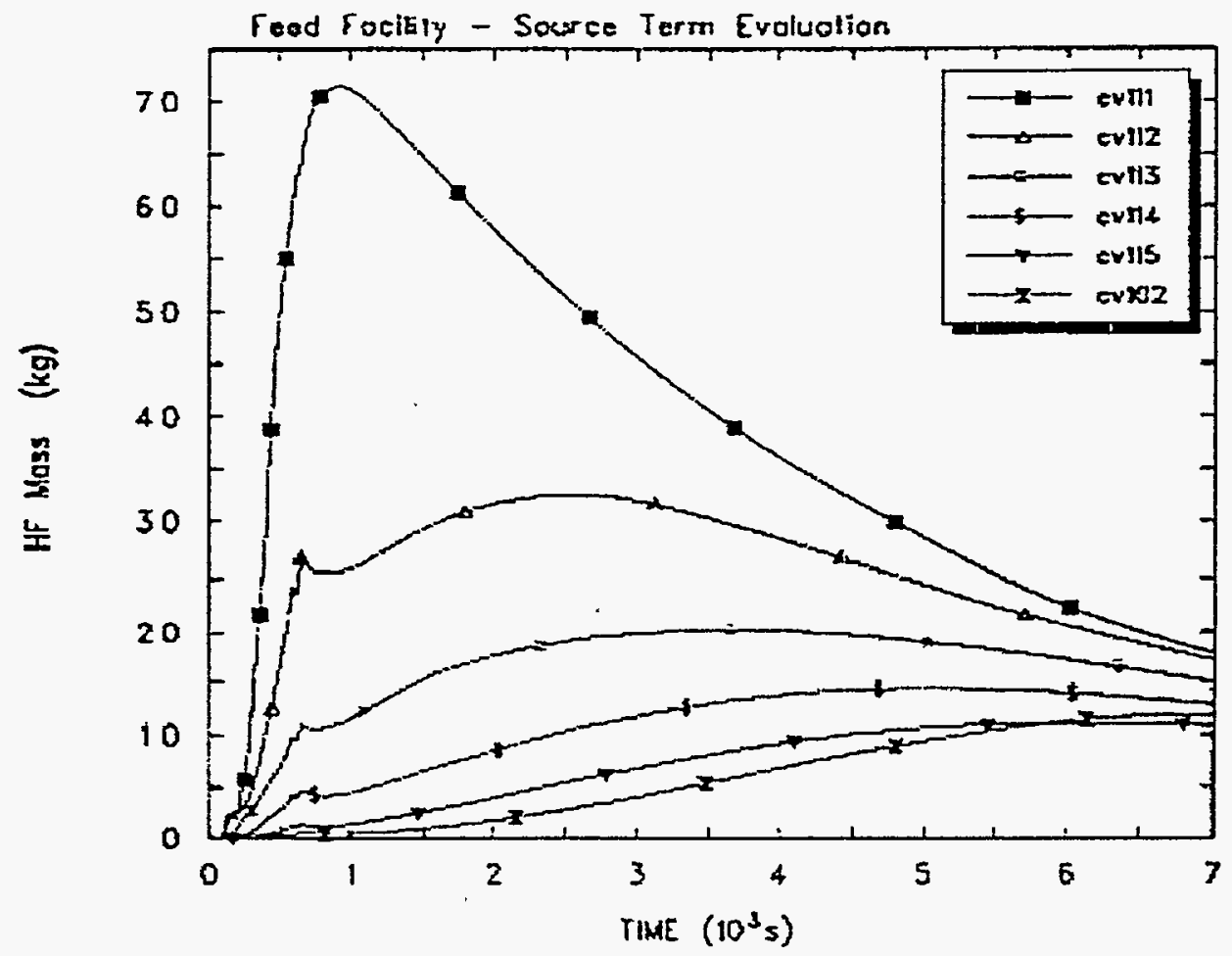

Figure 19. HF Mass Variations in Control Volumes (far-field wind velocity $=1 \mathrm{~cm} / \mathrm{s}$ ) 
Internal Distribution List

$\begin{array}{llll}\text { 1. } & \text { N.C.J. Chen } & 15-17 . & \text { R.P. Taleyarkhan } \\ \text { 2. } & \text { W.G. Craddick } & 18 . & \text { D. A. Walker } \\ \text { 3. } & \text { W.D. Goode } & & \text { ORNL Patent Section } \\ \text { 4. } & \text { E.C. Fox } & 19 & \text { Central Research Library } \\ \text { 5-9. } & \text { K.D. Keith } & 20 . & \text { K-25 Document Center } \\ \text { 10-12. } & \text { S.H. Kim } & 21 . & \text { Laboratory Records } \\ \text { 13. } & \text { D.A. Lombardi } & 22-23 . & \text { Department } \\ \text { 14. } & \text { R.W. Schmidt } & & \end{array}$

Paducah

24. Andy Bolyen, C-102-T-06

25. W. Allen Burnett, C-102-T

26. Hank Ford, C-102-T-06

27. John Joyce, C-102-T-06

28. James D. Sohl Jr., C-100-T

29-31. PGDP Record Copy

Portsmouth

32. Mark D. Hasty, $X-100$

33. Rick L. Mains, $X-100$

34. W. Dave Netzer, X-710

35. Ed Wagner, X-710

36-38. Ports Record Copy

External Distribution

39. J.C. Carter, 600 Forest Heights Drive, Knoxville, Tennessee, 37919

40. Randall M. Devault, 55 Jefferson, Oak Ridge, Tennessee, 37831

41. R.H. Dyer, Dyer Enterprises, 301 Old Suddath Road, Harriman, Tennessee 37748

42. P. G. Ellison, Lockheed Martin Idaho Technologies, Idaho National Engineering, Laboratory, P.O. Box 1625, Idaho Falls, Idaho 83415-3850

43. R.T. Lahey, Jr. JEC, Rensselaer Polytechnic Institute, Troy, New York, 121803590

44-45. DOE, Office of Scientific and Technical Information, P.O. Box 62, Oak Ridge, Tennessee 37831 